\title{
Roles of Tobacco Fractions in the Formation of Polycyclic Aromatic Amines in Tobacco Pyrolysis*
}

\author{
by \\ Shinya Yoshida ${ }^{1}$ and Kensei Kobayashi ${ }^{2}$ \\ ${ }^{1}$ Tobacco Science Research Center, Japan Tobacco Inc., Yokohama, Kanagawa, Japan \\ ${ }^{2}$ Graduate School of Engineering, Yokohama National University, Yokohama, Kanagawa, Japan
}

\section{SUMMARY}

The aim of the present study was to gain further understanding of the precursors in tobacco of four polycyclic aromatic amines (PAAs) - 1- and 2-aminonaphthalene, 3and 4-aminobiphenyl. We carried out non-isothermal pyrolysis of the residues, which were obtained after extraction of tobacco cut filler with methylene chloride followed by extraction with water, under three different pyrolysis conditions (target temperature $800{ }^{\circ} \mathrm{C} / 800{ }^{\circ} \mathrm{C} /$ $400{ }^{\circ} \mathrm{C}$ and $\mathrm{O}_{2}$ concentration in carrier gas $0 \% / 20 \% / 3 \%$, resp.). The yields of the four PAAs obtained by the pyrolysis of each sample were evaluated. Several nitrogenous components in the sample were also analyzed. The results under all these pyrolysis conditions showed that 1) the methylene chloride-soluble fraction, in which $50-60 \%$ of nicotine was extracted, did NOT contribute significantly contribution to the yields of the four PAAs; 2) the watersoluble fraction, in which most of the nitrogenous inorganic ions and amino acids were extracted, contributed at an average of about $30 \%$ to total PAA yield; and 3 ) the insoluble residue, in which only protein was detected during the investigation of the nitrogenous components in the present study, showed the highest contribution, $50-60 \%$ of the four PAAs formed. Consequently, it is concluded that protein-like components in tobacco contribute highly to the formation of the four PAAs by tobacco pyrolysis. [Beitr. Tabakforsch. Int. 25 (2013) 595-606]

\section{KEYWORDS}

Polycyclic aromatic amines, aminonaphthalene, aminobiphenyl, tobacco, smoke, tobacco extraction, pyrolysis, GC/MS analysis

\section{ZUSAMMENFASSUNG}

Das Ziel der vorliegenden Studie ist die Gewinnung neuer Erkenntnisse über die Vorläufer von vier polycyclischen aromatischen Aminen - 1- und 2-Aminonaphthalin, 3- und 4-Aminobiphenyl - im Tabak. Nach Extraktion von Schnitttabakeinlage mit Methylenchlorid und anschließender Extraktion mit Wasser erhaltene Rückstände wurden unter drei verschiedenen Pyrolysebedingungen (Zieltemperatur $800{ }^{\circ} \mathrm{C} / 800{ }^{\circ} \mathrm{C} / 400{ }^{\circ} \mathrm{C}$ und $\mathrm{O}_{2}$-Konzentration in Trägergas von $0 \% / 20 \% / 3 \%$ ) einer nicht-isothermen Pyrolyse unterzogen. Es wurden die Ausbeuten der vier PAA aus der Pyrolyse jeder Probe untersucht. Ebenso wurden mehrere stickstoffhaltige Bestandteile in der Probe analysiert. Die Ergebnisse unter allen untersuchten Pyrolysebedingungen zeigten, dass 1) die in Methylenchlorid lösliche Fraktion, in der 50-60\% Nikotin extrahiert wurde, KEINEN wesentlichen Beitrag zu den Ausbeuten der vier PAA ergab, 2) die wasserlösliche Fraktion, in der die meisten stickstoffhaltigen anorganischen Ionen und Aminosäuren extrahiert wurden, einen Beitrag in der durchschnittlichen Größenordnung von ca. 30\% der PAA-Gesamtausbeuten ergab und 3) die unlöslichen Rückstände, in denen bei der Untersuchung der stickstoffhaltigen Bestandteile in der vorliegenden Studie nur Protein nachgewiesen wurde, den höchsten Beitrag - 50-60\% der vier PAA - ergaben. Daraus wird geschlussfolgert, dass proteinähnliche Bestandteile im Tabak in hohem Maße zur Entstehung der vier PAA bei der Pyrolyse von Tabak beitragen. [Beitr. Tabakforsch. Int. 25 (2013) 595-606]

\section{RESUME}

L'objectif de la présente étude est d'approfondir la compréhension des précurseurs de quatre amines aromatiques 
polycycliques (AAP) - la 1-naphthylamine et la 2-naphthylamine ainsi que le 3-aminobiphényle et le 4-aminobiphényle-dans le tabac. Nous avons effectué une pyrolyse nonisotherme des résidus, ceux-ci ayant été obtenus après une extraction du tabac haché avec du dichlorométhane suivi d'une extraction avec de l'eau, dans trois conditions de pyrolyse (température cible $800{ }^{\circ} \mathrm{C} / 800{ }^{\circ} \mathrm{C} / 400{ }^{\circ} \mathrm{C}$ et concentration en $\mathrm{O}_{2}$ dans le gaz vecteur $0 \% / 20 \% / 3 \%$ respectivement). Les rendements des quatre AAP obtenues à partir de la pyrolyse de chaque échantillon ont été évalués. Plusieurs composants azotés dans l'échantillon ont également été analysés. Les résultats dans ces trois conditions de pyrolyse ont montré que 1) la fraction soluble dans le dichlorométhane, dans laquelle 50 à $60 \%$ de nicotine a été extrait, n'a PAS montré de contribution significative aux rendements des quatre AAP; 2) la fraction soluble dans l'eau, dans laquelle la plupart des ions inorganiques azotés et des acides aminés ont été extraits, a montré une contribution dont l'amplitude moyenne correspondait à env. 30\% des résultats totaux des AAP; et 3) les résidus insolubles, dans lesquels seules des protéines ont été détectées pendant l'analyse des composants azotés dans la présente étude, a montré la plus haute contribution, soit 50 à $60 \%$ des quatre AAP. Par conséquent, il a été conclu que les composants de type protéinique dans le tabac contribueraient hautement à la formation des quatre AAP dans la pyrolyse du tabac. [Beitr. Tabakforsch. Int. 25 (2013) 595-606]

\section{INTRODUCTION}

Aminonaphthalenes (AN) and aminobiphenyls (ABP), which are regarded as polycyclic aromatic amines (PAAs) and aniline-related compounds including those substituted on the ring, have been detected in oils derived from synthetic fuel technology (1), airborne particulate matters (2), synthetic food colorants (3), and cigarette smoke $(4,5)$. The methods to determine AN and ABP in cigarette smoke have been reported (5-8), and it has been estimated that proteins in tobacco are major precursors of these PAAs in tobacco smoke. PATRIANAKOS and HOFFMANN reported that the amounts of PAAs in mainstream smoke of cigarettes made with reconstituted tobacco sheet (RTS), from which tobacco proteins were partly removed, were lower than those in the mainstream smoke of untreated RTS cigarette (8). TORIKAI et al. showed that addition of bovine serum albumin (BSA) to tobacco increased the yield of either 2$\mathrm{AN}$ or 4-ABP in non-isothermal pyrolysis up to $800{ }^{\circ} \mathrm{C}$ under inert atmosphere (9). Both research groups concurred on the high contribution of tobacco proteins to the formation of PAAs, but they also mentioned the need for further investigation on the role of other nitrogenous tobacco components and on the contribution of endogenous proteins in tobacco.

The aim of the present study was to gain further understanding of the precursors of PAAs in tobacco. We used tobacco residues prepared by sequential extractions with methylene chloride followed by water, and evaluated the yields of four PAAs - 1- and 2-AN, 3- and 4-ABP - from the prepared tobacco sample using three different pyrolysis conditions. The determinations of several nitrogenous components in each tobacco sample were also carried out to clarify the relations between the tobacco components and the four PAAs. In addition, the residue, spiked with inorganic salts that were removed in a water extraction step, was also pyrolyzed to compare the contribution of inorganic nitrogenous ions and water-soluble organic nitrogenous components to the formation of the four PAAs. We also investigated the effects of the inorganic ions, e.g., alkaline metals, which were reported to affect the pyrolysis of biomass $(10,11)$, on the formation of the four PAAs.

\section{EXPERIMENTAL}

\section{Reagents and materials}

All reagents used were of analytical grade. Acetonitrile, methanol, hexane, methylene chloride, and D- $\alpha$-tocopherol were purchased from Wako Pure Chemical Industries Ltd. (Osaka, Japan). Hydrochloric acid $(\mathrm{HCl})$ aq., ammonia $\left(\mathrm{NH}_{3}\right)$ aq., and the inorganic salts were purchased from Kanto Chemical Co. Inc. (Tokyo, Japan). Trimethylamine (TMA) aq. and pentafluoropropionic acid anhydride (PFPA) were purchased from Sigma-Aldrich Chemical Co. (St. Louis, MO, USA). TMA was used as a hexane solution prepared by liquid-liquid extraction of TMA aq. with hexane before use. As the internal standards (ISTD) for the determination of PAAs, 1-AN-d7 and 3-ABP-d9 were purchased from $\mathrm{C} / \mathrm{D} / \mathrm{N}$ Isotopes Inc. (Quebec, Canada) and Toronto Research Chemical Inc. (Toronto, Canada), respectively. A spiking solution of ISTD was prepared in hexane, with a concentration of $1 \mu \mathrm{g} / \mathrm{mL} 1-\mathrm{AN}-\mathrm{d} 7$ and $0.2 \mu \mathrm{g} / \mathrm{mL} 3-A B P-d 9$. The unlabeled PAAs were obtained from Sigma-Aldrich Chemical Co. as a custom-ordered solution of 1-AN, 2-AN, and 4-ABP in hexane, whose concentrations in the solution were $1,000 \mu \mathrm{g} / \mathrm{mL}$, $1,000 \mu \mathrm{g} / \mathrm{mL}$, and $200 \mu \mathrm{g} / \mathrm{mL}$, respectively, except for 3ABP which was purchased from Tokyo Kasei Industry Co. Ltd. (Tokyo, Japan). Water used in the present study was purified with Gradient A-10 (Merck Millipore, Billerica, MA, USA). Protoporphyrin and chlorophyllin were purchased from Wako Pure Chemical Industries, Ltd. (Osaka, Japan) as reagent grade.

The flue-cured tobacco (FC) cut fillers and the Burley tobacco (BLY) cut fillers were obtained from Japan Tobacco Inc. (Tokyo, Japan) each as single grade tobacco. Kentucky Reference 2R4F and 3R4F cigarettes were obtained from the Kentucky Tobacco Research \& Development Center (University of Kentucky, Lexington, KY, USA). The $2 \mathrm{R} 4 \mathrm{~F}$ was replaced in 2008 by its successor the $3 \mathrm{R} 4 \mathrm{~F}$ due to diminishing stock of $2 \mathrm{R} 4 \mathrm{~F}$ for sale (12).

\section{Preparation of samples for validation of the determination method of PAAs}

Towards validation of the determination method of PAAs in the present study, a recovery study and comparison of determined values of PAAs in the mainstream smoke of Kentucky Reference cigarettes with reported values were carried out.

An aliquot of $20 \mathrm{~mL}$ of $0.2 \mathrm{~mol} / \mathrm{L} \mathrm{HCl}$ was spiked with $100 \mu \mathrm{L}$ of $0.17 \mu \mathrm{g} / \mu \mathrm{L} \mathrm{D}$ - $\alpha$-tocopherol in methanol, $100 \mu \mathrm{L}$ of the ISTD spiking solution, and the standard solution of 


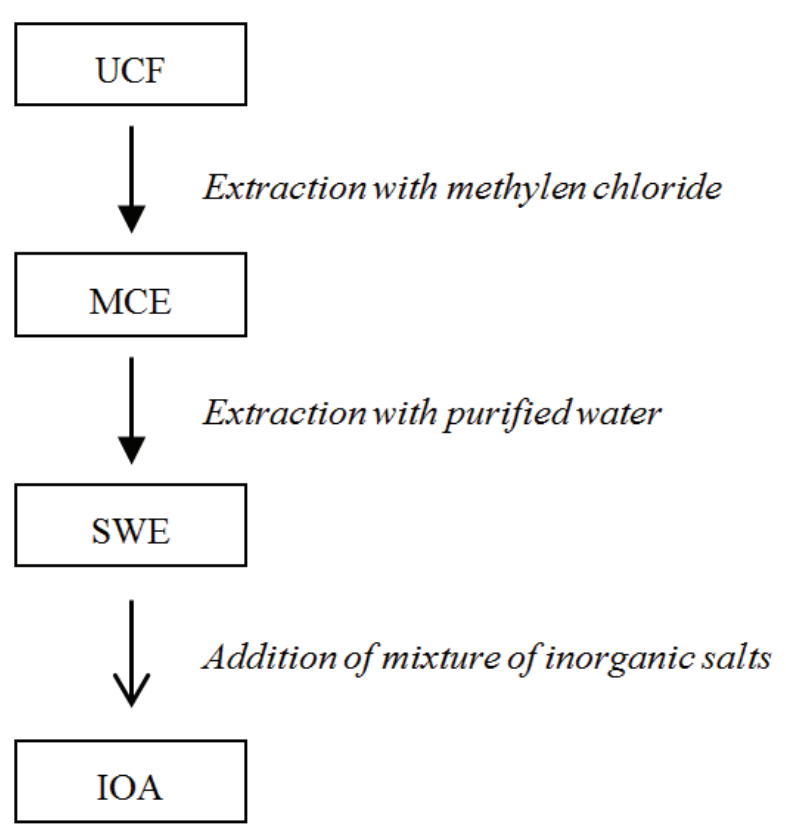

Figure 1. Scheme of tobacco sample preparation

The abbreviations in the figure stand for the following:

UCF: Untreated Cut Filler;

MCE: residue prepared by Methylene Chloride Extraction of UCF;

SWE: residue prepared by Sequential Water Extraction of MCE; IOA: residue prepared by the InOrganic salt Addition to SWE, to compensate for the ions lost in the water extraction step.

PAAs, and the prepared solution was then subjected to determination of PAAs to evaluate the recovery in a blank solution ( $\mathrm{HCl}$ aq.). Using an automated 10-port smoking machine (Cerulean SM410, Molins PLC, England, UK), 3R4F cigarettes were smoked under International Organization for Standardization (ISO) standard smoking condition (13) $(35.0 \mathrm{~mL}$ puff volume, 2-sec puff duration, one puff/min). The total particulate matter (TPM) of mainstream smoke from five cigarettes collected on a $44 \mathrm{~mm}$ Cambridge filter pad (Borgwaldt GmbH, Hamburg, Germany) was extracted with $30 \mathrm{~mL}$ of $0.2 \mathrm{~mol} / \mathrm{L} \mathrm{HCl}$. The extracted mixture was filtrated, and $20 \mathrm{~mL}$ of the filtrate was spiked with $100 \mu \mathrm{L}$ of $0.17 \mu \mathrm{g} / \mu \mathrm{L} \mathrm{D}$ - $\alpha$-tocopherol in methanol, $100 \mu \mathrm{L}$ of the ISTD spiking solution, and PAA standard solution, and the prepared solution was then used for the determination of PAAs as the sample to evaluate the recovery in a smoke matrix solution. PAAs in non-spiked samples were also determined in each case.

To determine PAAs in the smoke of reference cigarettes, TPM was collected on a $44 \mathrm{~mm}$ Cambridge filter pad from five cigarettes of either $2 \mathrm{R} 4 \mathrm{~F}$ or $3 \mathrm{R} 4 \mathrm{~F}$ types under ISO standard smoking conditions. The obtained TPM was treated as described in "Determination of PAAs in smoke". Each experiment for the validation was carried out in five replicates.

\section{Preparation of tobacco sample}

The scheme for preparation of the tobacco samples is shown in Figure 1. Using a rotary action shaker, SRR-2 (Asone Co., Osaka, Japan), $220 \mathrm{~g}$ of FC untreated cut filler
Table 1. Amount of inorganic salts added to SWE samples

\begin{tabular}{l|c|c}
\hline \multirow{2}{*}{ Inorganic salts } & \multicolumn{2}{|c}{ Amount added to 1 g WB of SWE $(\mathrm{mg})$} \\
\cline { 2 - 3 } & to FC-SWE & to BLY-SWE \\
\hline $\mathrm{KCl}$ & 9.8 & 16.0 \\
$\mathrm{~K}_{2} \mathrm{SO}_{4}$ & 19.6 & 14.4 \\
$\mathrm{~K}_{2} \mathrm{HPO}_{4}$ & 10.0 & 2.2 \\
$\mathrm{KNO}_{3}$ & - & 31.4 \\
$\mathrm{~K}_{2} \mathrm{CO}_{3}$ & 2.42 & - \\
$\mathrm{Mg}_{3}\left(\mathrm{PO}_{4}\right)_{2}$ & - & 7.2 \\
$\mathrm{MgCO}_{3}$ & 7.68 & 8.8 \\
$\left(\mathrm{NH}_{4}\right)_{2} \mathrm{CO}_{3}$ & - & 17.2 \\
Total & 49.5 & 97.2 \\
\hline
\end{tabular}

(UCF) on a wet basis (gWB) was extracted in a glass Erlenmeyer flask with $2.64 \mathrm{~L}$ of methylene chloride at room temperature (ca. $20^{\circ} \mathrm{C}$ ) for $3 \mathrm{~h}$. The extract and the residue were separated with a paper filter \#2 (125 mm; Advantec ${ }^{\circledR}$, Tokyo, Japan). After washing with $1 \mathrm{~L}$ of methylene chloride, the residue was dried in a draft chamber for $2 \mathrm{~h}$ and was then conditioned at $22{ }^{\circ} \mathrm{C}$ and $60 \%$ relative humidity for $48 \mathrm{~h}$ to obtain the residue of FC-UCF after the methylene chloride extraction (FC-MCE). Using the rotary action shaker, $100 \mathrm{gWB}$ of FC-MCE was extracted in a glass Erlenmeyer flask with $1.4 \mathrm{~L}$ of water at room temperature for $1 \mathrm{~h}$. The extract was removed and the residue was again extracted for $1 \mathrm{~h}$ with $1.4 \mathrm{~L}$ of water at room temperature. After separating the extracts using a resinous mesh, the residue from the second extraction was dried in a draft chamber for $4 \mathrm{~h}$ and was then conditioned at $22{ }^{\circ} \mathrm{C}$ and $60 \%$ relative humidity for $48 \mathrm{~h}$ to obtain the residue after sequential water extraction (FC-SWE). BLYUCF was also extracted in the same manner as FC-UCF to obtain BLY-MCE and BLY-SWE.

The mixture of inorganic salts was added to FC-SWE and BLY-SWE in the form of suspended aqueous solution. The added amount of each inorganic salt is shown in Table 1. The spiked residues were each conditioned at $22{ }^{\circ} \mathrm{C}$ and $60 \%$ relative humidity for $48 \mathrm{~h}$; thereafter referred to as FCIOA and BLY-IOA.

For spiking the tobacco cut filler with protoporphyrin or chlorophyllin, an aliquot of $20 \mathrm{~mL}$ of aqueous solutions of each porphine-containing compound $(0.05 \mathrm{~g} / \mathrm{mL})$ was sprayed on to $20 \mathrm{~g}$ of tobacco cut filler. Tobacco sprayed with purified water was also prepared as a control sample. The tobacco samples were conditioned at $22{ }^{\circ} \mathrm{C}$ and $60 \%$ relative humidity for over $48 \mathrm{~h}$ and then used in the pyrolysis experiments.

\section{Analysis of tobacco samples}

The weight of water together with traces of organic tobacco volatiles in each tobacco sample was obtained by subtracting the dry weight of the sample (drying condition: $100^{\circ} \mathrm{C}$, $1 \mathrm{~h}$ in an oven) from its wet weight. The recovery ratio of the dry weight of each prepared sample (FC- and BLY$\mathrm{MCE}$, or SWE) to that of the control sample (FC- and BLY-UCF) was calculated on a dry weight basis (DB). The total nitrogen, nicotine, ammonium ion, nitrate ion, amino acids, and proteins present in each tobacco sample, except for IOA, were quantified according to the proce- 


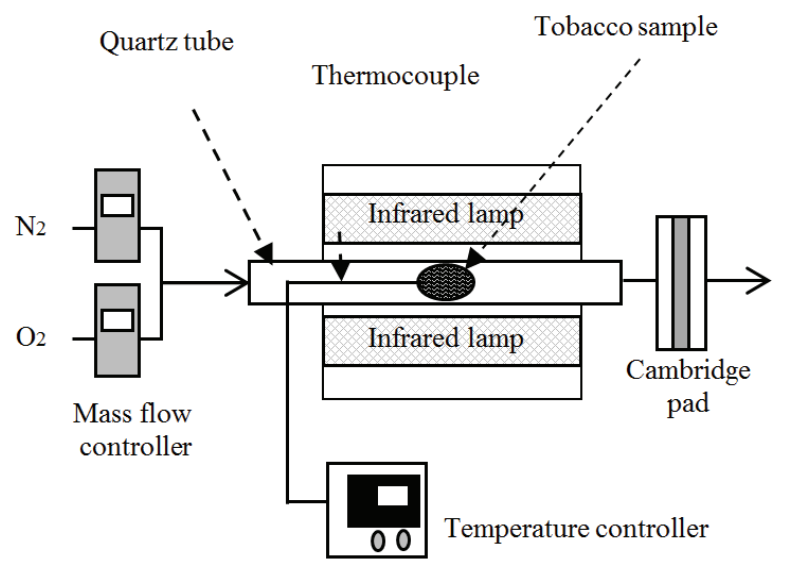

Figure 2. Schematic diagram of infrared pyrolyzer

dures reported by TORIKAI et al. (9) and references therein. The determination of chloride was carried out according to the procedure reported by BOKELMAN et al. (14). The quantities of potassium, calcium, magnesium, sulfur and phosphorus present were determined by inductively coupled plasma - atomic emission spectroscopy (ICP-AES) ICPE-9000 (Shimadzu Co., Kyoto, Japan) after a microwave digestion (15) of each tobacco sample. The determination of each tobacco component was done in triplicate.

\section{Pyrolysis experiment}

The pyrolysis apparatus used in the present study was the same as that employed by TORIKAI et al. $(9,16)$. In brief, $150 \mathrm{mg}$ wet weight basis of tobacco sample was placed at the center of a quartz tube $(416 \mathrm{~mm} \times 8 \mathrm{~mm}$ i.d., $1 \mathrm{~mm}$ thick), and was heated from room temperature by an infrared device up to the target temperature under carrier gas flow (Figure 2). The temperature of the tobacco was monitored by a thermocouple during the pyrolysis experiment. TPM generated from the tobacco sample was collected on a $44 \mathrm{~mm}$ Cambridge filter pad during the pyrolysis. The PAAs that we focused on were not detected in the gas passing through the Cambridge filter pad.

In the present study, three different conditions (Table 2) were applied to the pyrolysis of each tobacco sample. These three conditions were chosen to reflect the conditions observed inside a burning cigarette during puffing (17). However, it should be pointed out that the reproduction of the conditions in a burning cigarette in a pyrolysis experiment has limitations due to the complexity of dynamic physical and chemical processes occurring inside the burning cigarette, as discussed by BAKER (18).

Each pyrolysis experiment was carried out in triplicate.

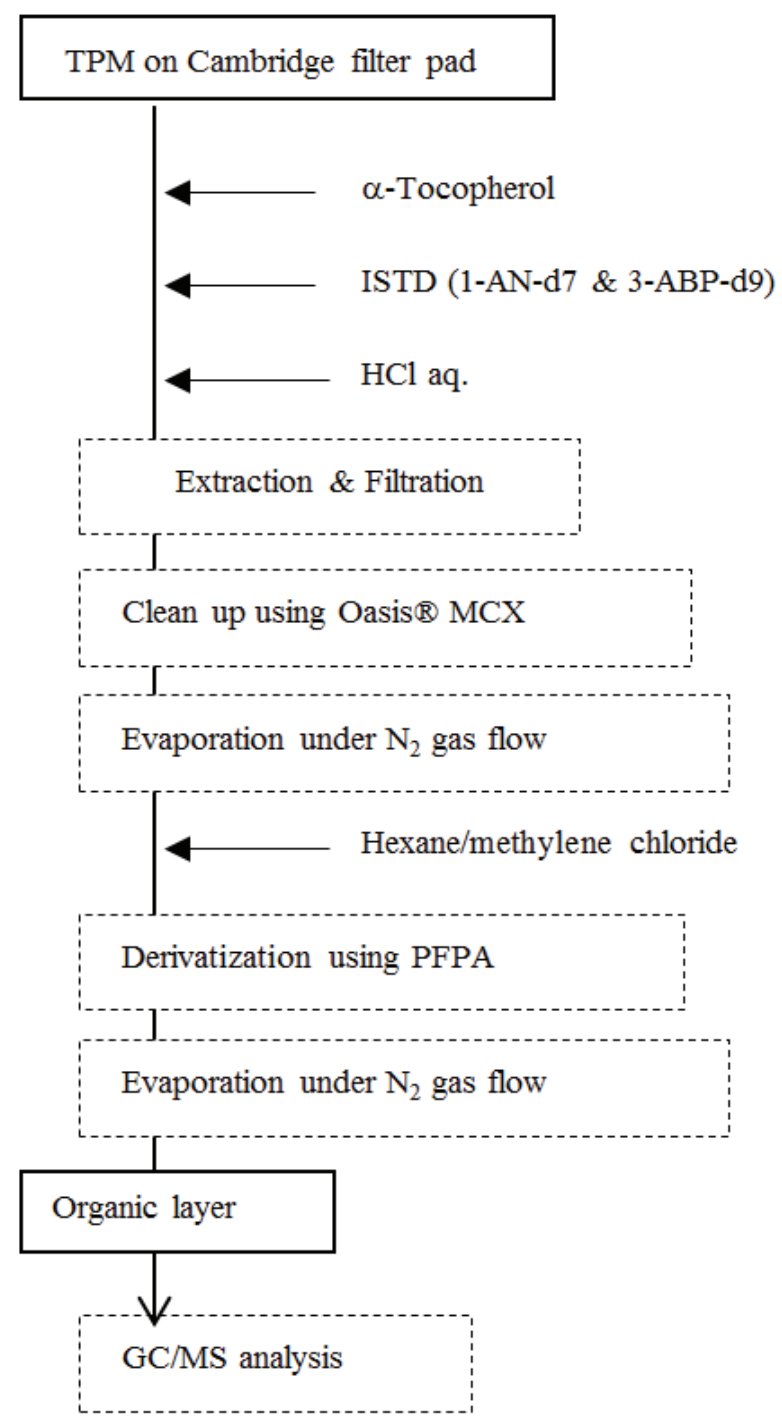

Figure 3. Pre-treatment steps of TPM for the determination of PAAs.

\section{Determination of PAAs in smoke}

The pre-treatment steps for TPM are shown in Figure 3. After collection of TPM, the Cambridge pad placed in a PTFE Erlenmeyer flask was spiked with $100 \mu \mathrm{L}$ of $0.17 \mu \mathrm{g} / \mu \mathrm{L} \mathrm{D}$ - $\alpha$-tocopherol in methanol and $100 \mu \mathrm{L}$ of the ISTD spiking solution, and was extracted with $30 \mathrm{~mL}$ of $0.2 \mathrm{~mol} / \mathrm{L} \mathrm{HCl}$ for $60 \mathrm{~min}$ by using a wrist-action shaker. A $20 \mathrm{~mL}$ aliquot of the filtered $\mathrm{HCl}$ extract was applied to the solid-phase extraction (SPE) cartridge Oasis ${ }^{\circledR}$ MCX

Table 2. Pyrolysis conditions in the present study.

\begin{tabular}{|c|c|c|c|c|c|}
\hline \multirow[b]{2}{*}{ Code } & \multicolumn{4}{|c|}{ Pyrolysis condition } & \multirow{2}{*}{$\begin{array}{l}\text { Corresponding locus in the } \\
\text { burning cigarette }\end{array}$} \\
\hline & $\begin{array}{l}\text { Target temperature } \\
\left({ }^{\circ} \mathrm{C}\right) \\
\end{array}$ & $\begin{array}{l}\text { Heating rate } \\
\left({ }^{\circ} \mathrm{C} / \mathrm{min}\right)\end{array}$ & $\begin{array}{c}\text { Atmosphere } \\
\left(\% \text { of } \mathrm{O}_{2} \text { in } \mathrm{N}_{2}\right)\end{array}$ & $\begin{array}{c}\text { Carrier gas flow rate } \\
(\mathrm{mL} / \mathrm{min})\end{array}$ & \\
\hline (A) & 800 & 1000 & 0 & 1000 & Center of the cone \\
\hline (B) & 800 & 1000 & 20 & 1000 & Near char line \\
\hline (C) & 400 & 1000 & 3 & 1000 & Mouthend-side of the cone \\
\hline
\end{tabular}




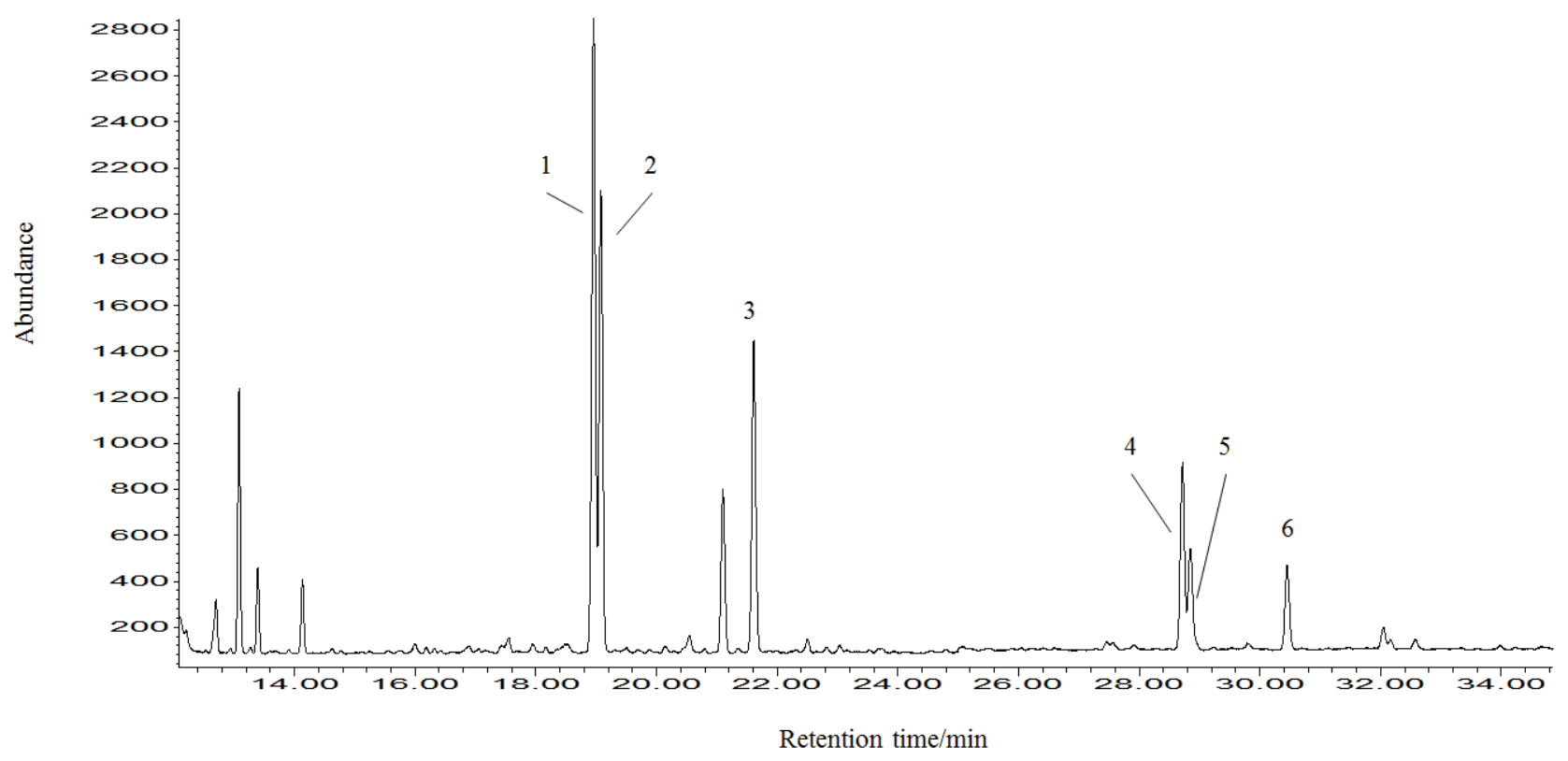

Figure 4. The total ion current (TIC) chromatogram of the pentafluoropropionate derivatives of the four PAAs in the mainstream smoke matrix of the 2R4F with the current clean-up method.

All PAAs including ISTD were detected as their pentafluorpropionate derivatives. 1) 1-aminonaphthalene-d7 (ISTD), 2) 1-aminonaphthalene, 3) 2-aminonaphthalene, 4) 3-aminobiphenyl-d9 (ISTD), 5) 3-aminobiphenyl, 6) 4-aminobiphenyl.

(150 mg of sorbent, $6 \mathrm{~mL}$ in volume: Nihon Waters K.K., Tokyo, Japan) (7). After rinsing the cartridge with $2 \mathrm{~mL}$ of acetonitrile, the compounds retained on the MCX cartridge were eluted with $7 \mathrm{~mL}$ of $2.5 \% \mathrm{NH}_{3}$ in methanol into a glass test tube. Using TurboVap-LV (SOTAX Co., Hopkinton, MA, USA), the eluate was concentrated at $40{ }^{\circ} \mathrm{C}$ under $\mathrm{N}_{2}$ flow to about $300 \mu \mathrm{L}$, but not to dryness. An aliquot of $6 \mathrm{~mL}$ of the mixture of hexane and methylene chloride (4:1, $\mathrm{v} / \mathrm{v})$ was added to the residual solution in the test tube. The resulting solution was spiked with $50 \mu \mathrm{L}$ of TMA solution in hexane followed by $50 \mu \mathrm{L}$ of PFPA. After keeping at room temperature for $60 \mathrm{~min}$, the resulting mixture was concentrated at $40{ }^{\circ} \mathrm{C}$ under $\mathrm{N}_{2}$ flow to a dark brown liquid concentrate. The derivatized PAAs in the concentrate were extracted with $250 \mu \mathrm{L}$ of the mixture of hexane and methylene chloride $(4: 1, \mathrm{v} / \mathrm{v})$. The upper layer was transferred to a brown vial with a glass insert and subjected to analysis by gas chromatography with electron impact mass spectrometry (GC/EI-MS).

The sample analysis was performed on an Agilent 6890/ $5973 \mathrm{~N}$ equipped with HP-5MS column $(30 \mathrm{~m} \times 0.25 \mathrm{~mm}$ i.d., $0.25 \mu \mathrm{m}$ in film thickness). The analytical conditions were as follows: injection volume $1 \mu \mathrm{L}$ (pulsed splitless at $193 \mathrm{kPa}\left(28 \mathrm{psi}\right.$ ) pulse pressure); inlet temperature $250^{\circ} \mathrm{C}$; oven heating program $45^{\circ} \mathrm{C}$ for $2 \mathrm{~min}$, heated to $120^{\circ} \mathrm{C}$ at $20^{\circ} \mathrm{C} / \mathrm{min}$ and then to $180{ }^{\circ} \mathrm{C}$ at $2{ }^{\circ} \mathrm{C} / \mathrm{min}$ and further to $250{ }^{\circ} \mathrm{C}$ at $20^{\circ} \mathrm{C} / \mathrm{min}$ with a final hold time of $5 \mathrm{~min}$; carrier gas and flow rate $\mathrm{He}$ at $1 \mathrm{~mL} / \mathrm{sec}$ (constant flow mode); detector inlet temperature $250{ }^{\circ} \mathrm{C}$; EI energy $70 \mathrm{eV}$; MS mode selected ion monitoring (SIM) mode; monitored ion $\mathrm{m} / \mathrm{z} 289$ for the derivatized AN, 296 for the derivatized AN$\mathrm{d} 7,315$ for the derivatized ABP, and 324 for the derivatized ABP-d9.

\section{Data comparison}

The dry weight of original tobacco changes at the extraction step or on addition of some reagent. In the present study, the determined values were compared based on the weight corresponding to $1 \mathrm{~g}$ of UCF dry weight according to the following equation.

$C_{\text {compared }}=C_{\text {obtained }} \times D R$

$C_{\text {compared }}$ : data used for the comparison (g/g DB of UCF)

$C_{\text {obtained }}$ : determined value ( $\mathrm{g} / \mathrm{g}$ DB of each sample)

$D R: \quad$ dry weight ratio of treated samples to UCF (g DB of each sample/g DB of UCF)

\section{RESULTS}

Validation of the determination method for PAAs

To validate the determination method for the PAAs used in the present study, we evaluated the recovery of the standard reagent, and also compared the determined values of PAAs in the mainstream smoke of reference cigarettes with the reported values.

The total ion current (TIC) chromatogram of the pentafluoropropionate derivatives of the four PAAs in the mainstream smoke matrix of the $2 \mathrm{R} 4 \mathrm{~F}$ with the current clean-up method is shown in Figure 4. The peak of each PAA was obtained with good separation and peak sharpness.

The percent recoveries of the standard reagents are shown in Table 3 as an average of five replicates. "In blank" and "In smoke matrix" in Table 3 indicate recovery with the addition of standard reagents to a blank solvent $(0.2 \mathrm{~mol} / \mathrm{L}$ 
Table 3. Recovery ratio of PAAs using the present method.

\begin{tabular}{l|ccc}
\hline \multirow{2}{*}{ PAAs } & \multicolumn{3}{|c}{ Recovery (\%) } \\
\cline { 2 - 4 } & In blank $^{\text {a }}$ & In matrix (a) & In matrix (b) \\
\hline 1-AN & 98 & 99 & 103 \\
2-AN & 104 & 78 & 82 \\
3-ABP & 92 & 84 & 89 \\
4-ABP & 95 & 92 & 94 \\
\hline
\end{tabular}

a The spiking conditions in Table 3 were as follows: "In blank": addition of $25 \mathrm{ng}$ of 1 - and 2-AN, and $5 \mathrm{ng}$ of 3 - and $4-\mathrm{ABP}$ to $0.2 \mathrm{~mol} / \mathrm{L}$ hydrochloric acid

"In matrix (a)": addition of $25 \mathrm{ng}$ of 1 - and 2-AN, and $5 \mathrm{ng}$ of 3and 4-ABP to an extracted solution of the mainstream smoke of the $3 \mathrm{R} 4 \mathrm{~F}$ with $0.2 \mathrm{~mol} / \mathrm{L}$ hydrochloric acid

"In matrix (b)": addition of 50 ng of 1- and 2-AN, and 10 ng of 3- and 4-ABP to the same extracted solution as used for the preparation of "In matrix (a)".

hydrochloric acid) and an extracted solution of mainstream smoke of the $3 \mathrm{R} 4 \mathrm{~F}$ with $0.2 \mathrm{~mol} / \mathrm{L}$ hydrochloric acid. The difference between "matrix (a)" and "matrix (b)" is the spiking amount of standard reagents. The good recoveries, $78-104 \%$, were obtained by using the present method for the four PAAs either in the blank solution or in the smoke matrix solutions.

The determined values of the four PAAs in the mainstream smoke of Kentucky Reference cigarettes obtained by the present method are shown in Table 4. Reported values are also shown in the same table. The results of 2R4F obtained by
Table 5. Dry weight ratio of tobacco samples to UCF. The value with an asterisk was obtained by adding the mixture of inorganic compounds to SWE.

\begin{tabular}{l|c|c}
\hline \multirow{2}{*}{ Samples } & \multicolumn{2}{|c}{ Dry weight ratio [-] } \\
\cline { 2 - 3 } & FC & BLY \\
\hline UCF & 1.00 & 1.00 \\
MCE & 0.88 & 0.88 \\
SWE & 0.53 & 0.58 \\
IOA $\left(^{*}\right)$ & 0.56 & 0.63 \\
\hline
\end{tabular}

the present method were found to be comparable to the reported values $(5,7)$. The relative yields of $2-A N$ and $4-A B P$ of the 3R4F compared to the 2R4F obtained by the present method were $94 \%$ and $93 \%$ and found to be comparable to the results reported by ROEMER et al., which were $98 \%$ and $97 \%$ (12).

The advantage of the present method is to allow us to determine PAAs in cigarette smoke by a generic GC/MS system without using additional detectors such as MS equipped with negative ion chemical ionization (7) or tandem MS/MS (6).

\section{Analysis of the tobacco samples}

The dry weight ratio of each sample to UCF is shown in Table 5. The sequential extraction steps with methylene chloride and water resulted in weight losses of about $12 \%$ and $30 \%$ of the dry weight of UCF.

The amounts of tobacco components in each sample are

Table 4. Determined levels of PAAs in the mainstream smoke of 2R4F and 3R4F under ISO smoking conditions, and the PAA levels in $3 \mathrm{R} 4 \mathrm{~F}$ relative to $2 \mathrm{R} 4 \mathrm{~F}$

\begin{tabular}{|c|c|c|c|c|c|c|c|}
\hline \multirow{3}{*}{ PAAs } & \multirow{2}{*}{\multicolumn{2}{|c|}{$\begin{array}{c}\text { 3R4F } \\
\text { Present method (ng/cig) }\end{array}$}} & \multicolumn{4}{|c|}{$2 \mathrm{R} 4 \mathrm{~F}$} & \multirow{3}{*}{$\begin{array}{l}3 \mathrm{R} 4 \mathrm{~F} \text { to } 2 \mathrm{R} 4 \mathrm{~F} \text { ratio } \\
\text { Present method (\%) }\end{array}$} \\
\hline & & & \multicolumn{2}{|c|}{ Present method (ng/cig) } & \multirow{2}{*}{$\begin{array}{l}\text { Ref. (5) } \\
\text { (ng/cig) }\end{array}$} & \multirow{2}{*}{$\begin{array}{l}\text { Ref. (7) } \\
\text { (ng/cig) }\end{array}$} & \\
\hline & Average & SD & Average & SD & & & \\
\hline $1-\mathrm{AN}$ & 12.72 & 0.69 & 13.29 & 0.99 & $6.11-17.08$ & 17.00 & 96 \\
\hline 2-AN & 8.79 & 0.53 & 9.38 & 0.55 & $3.03-10.57$ & 8.60 & 94 \\
\hline 3-ABP & 2.28 & 0.10 & 2.42 & 0.12 & $0.82-3.09$ & 2.95 & 95 \\
\hline 4-ABP & 1.76 & 0.05 & 1.90 & 0.08 & $0.68-1.93$ & 1.60 & 93 \\
\hline
\end{tabular}

Table 6. Amount of tobacco components in the tobacco samples.

\begin{tabular}{|c|c|c|c|c|c|c|}
\hline \multirow{2}{*}{ Components } & \multicolumn{3}{|c|}{$\mathrm{FC}(\mathrm{mg} / \mathrm{g}$ DB of CTRL) } & \multicolumn{3}{|c|}{$\mathrm{BLY}(\mathrm{mg} / \mathrm{g}$ DB of CTRL) } \\
\hline & UCF & MCE & SWE & UCF & MCE & SWE \\
\hline Total nitrogen & 28.3 & 22.9 & 11.1 & 51.7 & 43.1 & 18.9 \\
\hline Nicotine & 33.1 & 17.5 & 1.3 & 41.9 & 15.9 & 1.1 \\
\hline Ammonia & 0.45 & 0.40 & 0.06 & 6.2 & 5.1 & 0.3 \\
\hline Nitrate & 0.23 & 0.20 & trace & 4.6 & 3.9 & 0.1 \\
\hline Amino acid (total) & 11.2 & 11.3 & 0.3 & 36.1 & 37.2 & 1.8 \\
\hline Protein & 60.1 & 55.4 & 37.8 & 80.4 & 78.9 & 69.4 \\
\hline Chlorine & 4.7 & 4.1 & trace & 7.8 & 6.5 & 0.2 \\
\hline Potassium & 24.5 & 23.4 & 2.2 & 32.5 & 30.9 & 2.4 \\
\hline Magnesium & 5.3 & 5.1 & 1.4 & 6.0 & 6.0 & 1.1 \\
\hline Calcium & 16.5 & 15.2 & 9.8 & 37.5 & 37.1 & 20.1 \\
\hline Phosphorus & 2.4 & 2.3 & 0.3 & 2.9 & 2.8 & 0.4 \\
\hline Sulfur & 5.7 & 5.4 & 1.0 & 5.8 & 5.6 & 1.6 \\
\hline
\end{tabular}



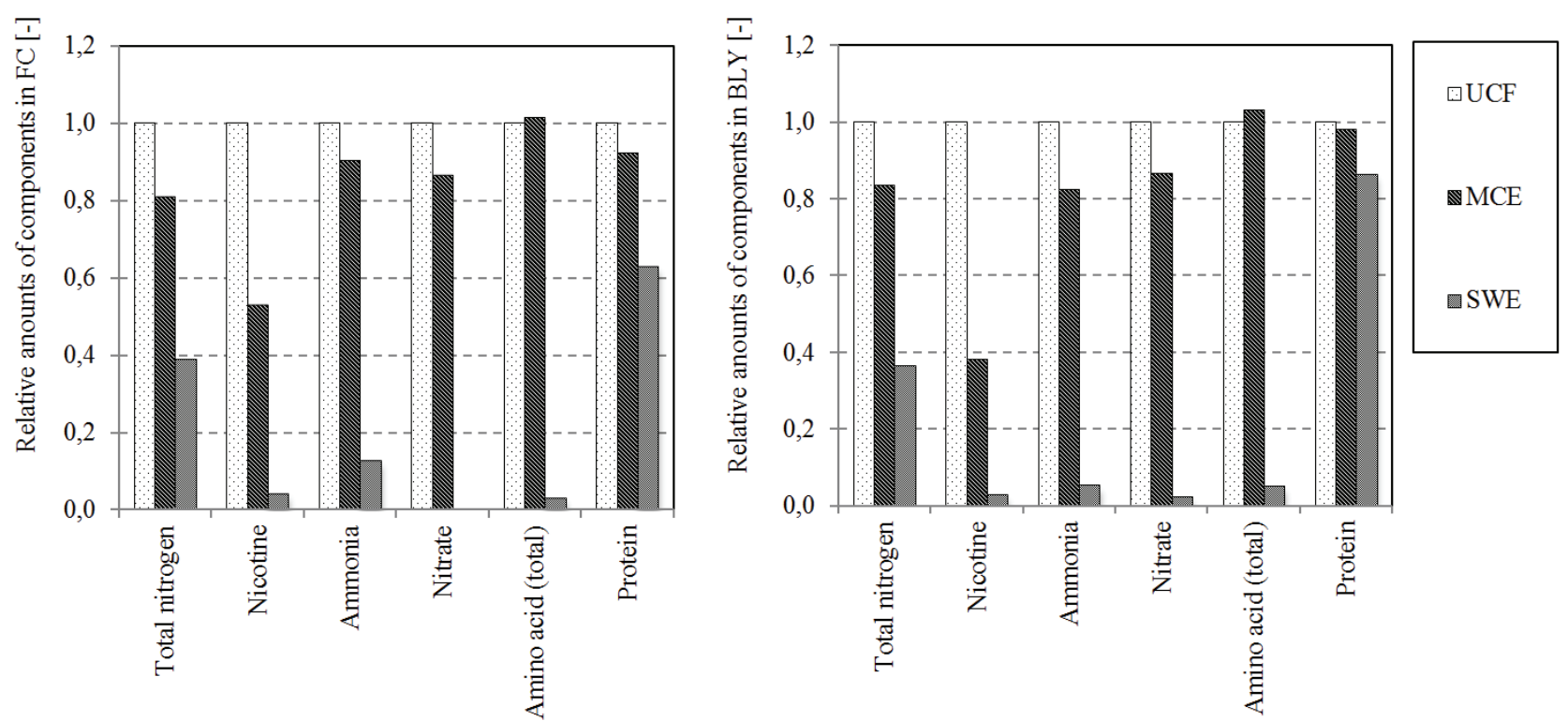

Figure 5. Relative amounts of nitrogenous components in FC samples (left) and BLY samples (right) normalized by each amount in UCF.
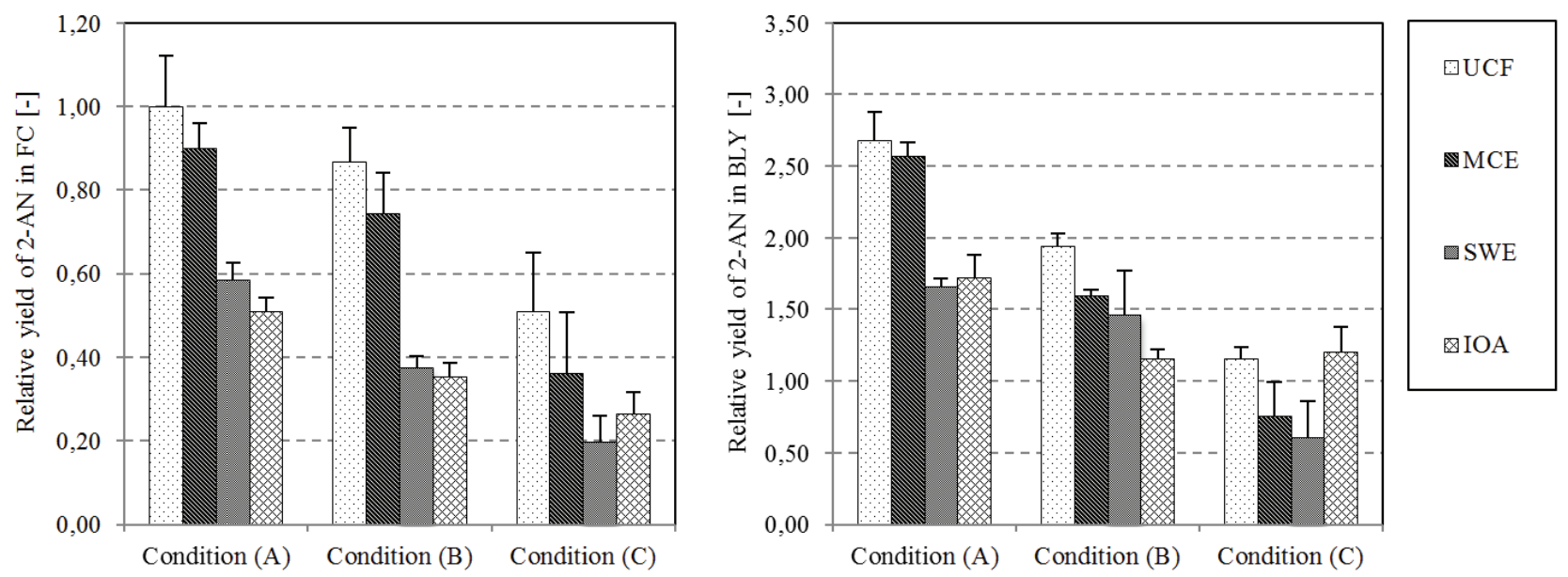

Figure 6. Relative yield of 2-AN in the pyrolysis of FC samples (left) and BLY samples (right) under three pyrolysis conditions. All results were normalized by the yields of FC-UCF under the condition (A). The conditions (A), (B), and (C) are described in Table 2.

shown in Table 6 . These results are corrected by considering the dry weight ratio of each sample to UCF as described in the EXPERIMENTAL section. The amounts of each tobacco component in UCF were found to be comparable to the reported values $(9,14,18)$.

Figure 5 shows the relative amounts of nitrogenous components in the samples normalized by the result of each UCF. Nicotine was extracted into methylene chloride at $50 \%$ and $60 \%$ of the original amount in the case of FC and BLY, respectively. The residual nicotine was extracted into water. Over $80 \%$ of the total amounts of ammonia, nitrate and amino acids were extracted into water. Regarding protein, about $60 \%$ of the original amount was retained in the water-extracted residue (FC-SWE) and the remaining parts were extracted into water in the case of FC. In the case of BLY, ca. $90 \%$ of total protein remained in the insoluble residue (BLY-SWE).
The results of analyses of nitrogenous components in each sample showed: 1) nicotine was distributed into both the methylene chloride-soluble and the water-soluble fractions; 2) almost all the ammonia, nitrate and amino acids were extracted into the water-soluble fraction; and 3) protein remained mainly in the insoluble fraction.

\section{Yields of aromatic amines in pyrolysis of tobacco samples}

In this section, the results of 2-AN and 4-ABP are shown, and the differences between the results of these two PAAs and those of their regio-isomers, 1-AN and 3-ABP, are described. The yields of the four PAAs obtained under the pyrolysis conditions (A), (B) and (C) (see Table 2) are shown in Table 7, 8 and 9.

The relative yields of 2-AN normalized by the yields from FC-UCF under the condition (A) are shown in Figure 6. In 
Table 7. Yields of PAAs obtained by the pyrolysis of tobacco samples under the pyrolysis conditions (A) in ng/g DB of CTRL. $800{ }^{\circ} \mathrm{C}$ as the target temperature in a non-isothermal pyrolysis; $0 \%$ as the concentration of $\mathrm{O}_{2}$ in the $\mathrm{N}_{2}$ carrier gas.

\begin{tabular}{|c|c|c|c|c|c|c|c|c|c|}
\hline \multirow{2}{*}{ Tobacco type } & \multirow{2}{*}{ Sample type } & \multicolumn{2}{|c|}{$1-\mathrm{AN}$} & \multicolumn{2}{|c|}{ 2-AN } & \multicolumn{2}{|c|}{ 3-ABP } & \multicolumn{2}{|c|}{ 4-ABP } \\
\hline & & Average & SD & Average & SD & Average & SD & Average & SD \\
\hline \multirow{4}{*}{$\mathrm{FC}$} & UCF & 320 & 45 & 203 & 25 & 41 & 6 & 29 & 4 \\
\hline & MCE & 289 & 28 & 183 & 12 & 39 & 4 & 28 & 2 \\
\hline & SWE & 151 & 12 & 119 & 8 & 29 & 2 & 19 & 1 \\
\hline & $\mathrm{IOA}$ & 191 & 23 & 103 & 7 & 30 & 4 & 19 & 2 \\
\hline \multirow{4}{*}{ BLY } & UCF & 826 & 76 & 544 & 41 & 133 & 15 & 111 & 12 \\
\hline & MCE & 790 & 22 & 522 & 19 & 136 & 5 & 114 & 2 \\
\hline & SWE & 474 & 14 & 338 & 10 & 84 & 2 & 66 & 1 \\
\hline & $\mathrm{IOA}$ & 602 & 47 & 349 & 33 & 100 & 7 & 79 & 6 \\
\hline
\end{tabular}

Table 8. Yields of PAAs obtained by the pyrolysis of tobacco samples under the pyrolysis conditions (B) in ng/gDB of CTRL. $800{ }^{\circ} \mathrm{C}$ as the target temperature in a non-isothermal pyrolysis; $20 \%$ as the concentration of $\mathrm{O}_{2}$ in the $\mathrm{N}_{2}$ carrier gas.

\begin{tabular}{|c|c|c|c|c|c|c|c|c|c|}
\hline \multirow{2}{*}{ Tobacco type } & \multirow{2}{*}{ Sample type } & \multicolumn{2}{|c|}{ 1-AN } & \multicolumn{2}{|c|}{$2-A N$} & \multicolumn{2}{|c|}{ 3-ABP } & \multicolumn{2}{|c|}{ 4-ABP } \\
\hline & & Average & SD & Average & SD & Average & SD & Average & SD \\
\hline \multirow{4}{*}{ FC } & UCF & 287 & 28 & 176 & 16 & 38 & 4 & 29 & 4 \\
\hline & MCE & 257 & 23 & 151 & 20 & 34 & 3 & 27 & 4 \\
\hline & SWE & 110 & 7 & 76 & 6 & 23 & 1 & 16 & 0.1 \\
\hline & IOA & 131 & 10 & 72 & 7 & 22 & 1 & 16 & 1 \\
\hline \multirow{4}{*}{ BLY } & UCF & 658 & 50 & 394 & 17 & 107 & 4 & 95 & 1 \\
\hline & MCE & 561 & 10 & 325 & 8 & 93 & 2 & 82 & 2 \\
\hline & SWE & 396 & 58 & 297 & 63 & 70 & 7 & 52 & 3 \\
\hline & IOA & 408 & 12 & 236 & 12 & 71 & 2 & 56 & 1 \\
\hline
\end{tabular}

Table 9. Yields of PAAs obtained by the pyrolysis of tobacco samples under the pyrolysis conditions (C) in ng/g DB of CTRL. $400{ }^{\circ} \mathrm{C}$ as the target temperature in a non-isothermal pyrolysis; $3 \%$ as the concentration of $\mathrm{O}_{2}$ in the $\mathrm{N}_{2}$ carrier gas.

\begin{tabular}{|c|c|c|c|c|c|c|c|c|c|}
\hline \multirow{2}{*}{ Tobacco type } & \multirow{2}{*}{ Sample type } & \multicolumn{2}{|c|}{ 1-AN } & \multicolumn{2}{|c|}{ 2-AN } & \multicolumn{2}{|c|}{ 3-ABP } & \multicolumn{2}{|c|}{ 4-ABP } \\
\hline & & Average & SD & Average & SD & Average & SD & Average & SD \\
\hline \multirow{4}{*}{ FC } & UCF & 184 & 41 & 104 & 29 & 24 & 5 & 21 & 4 \\
\hline & MCE & 136 & 45 & 74 & 30 & 18 & 6 & 18 & 5 \\
\hline & SWE & 56 & 13 & 40 & 13 & 13 & 3 & 11 & 1 \\
\hline & $\mathrm{IOA}$ & 100 & 16 & 53 & 11 & 16 & 2 & 13 & 1 \\
\hline \multirow{4}{*}{ BLY } & UCF & 454 & 8 & 235 & 16 & 61 & 1 & 60 & 3 \\
\hline & MCE & 347 & 76 & 153 & 49 & 47 & 10 & 49 & 7 \\
\hline & SWE & 199 & 52 & 123 & 53 & 32 & 8 & 31 & 6 \\
\hline & IOA & 439 & 24 & 245 & 35 & 56 & 5 & 48 & 3 \\
\hline
\end{tabular}

each case, the yield of 2-AN from SWE was 40-70\% of that from UCF. Although some results, especially under condition $(\mathrm{C})$, showed larger variation, the water extraction of MCE indicated higher reduction in 2-AN yield than the methylene chloride extraction of UCF, especially under high target temperature conditions such as the conditions (A) and (B). Comparing IOA with SWE, no significant change in 2AN yield was observed under either condition (A) or (B). Under the condition $(C)$, where non-isothermal pyrolysis up to $400{ }^{\circ} \mathrm{C}$ was performed, the yield of $2-\mathrm{AN}$ seemed to be increased by the addition of inorganic compounds. In a previous study (10), it was reported that alkali metal ions, such as potassium, had the effect of promoting thermal decomposition of polymers in biomass. It seems that the effects of inorganic compounds observed under condition (C) were due to the catalytic promotion of the decomposition of the nitrogenous components remaining in SWE.
Although the results of 4-ABP (Figure 7) were in most cases similar to those of 2-AN, interesting results were obtained on adding inorganic compounds to SWE. Comparing IOA with SWE, a significant increase in 4-ABP yield was observed in the case of BLY samples under the conditions (A) and (C), but not under the condition (B). Condition (B) was a combustion rather than pyrolysis. No significant effect from the addition of inorganic compounds was observed in the case of FC. As shown in Table 1, ammonium and nitrate ions were added only to BLY-SWE because of their low levels in FC-UCF (Table 6). Regarding the effects of the addition of inorganic compounds under the pyrolysis conditions (A) and (C), it is assumed that the difference between BLY-SWE and FC-SWE is caused by the content of these nitrogenous inorganic ions. The incorporation of ${ }^{15} \mathrm{~N}$ into $4-\mathrm{ABP}$ was observed in the pyrolysis of flue-cured cut tobacco spiked with either 

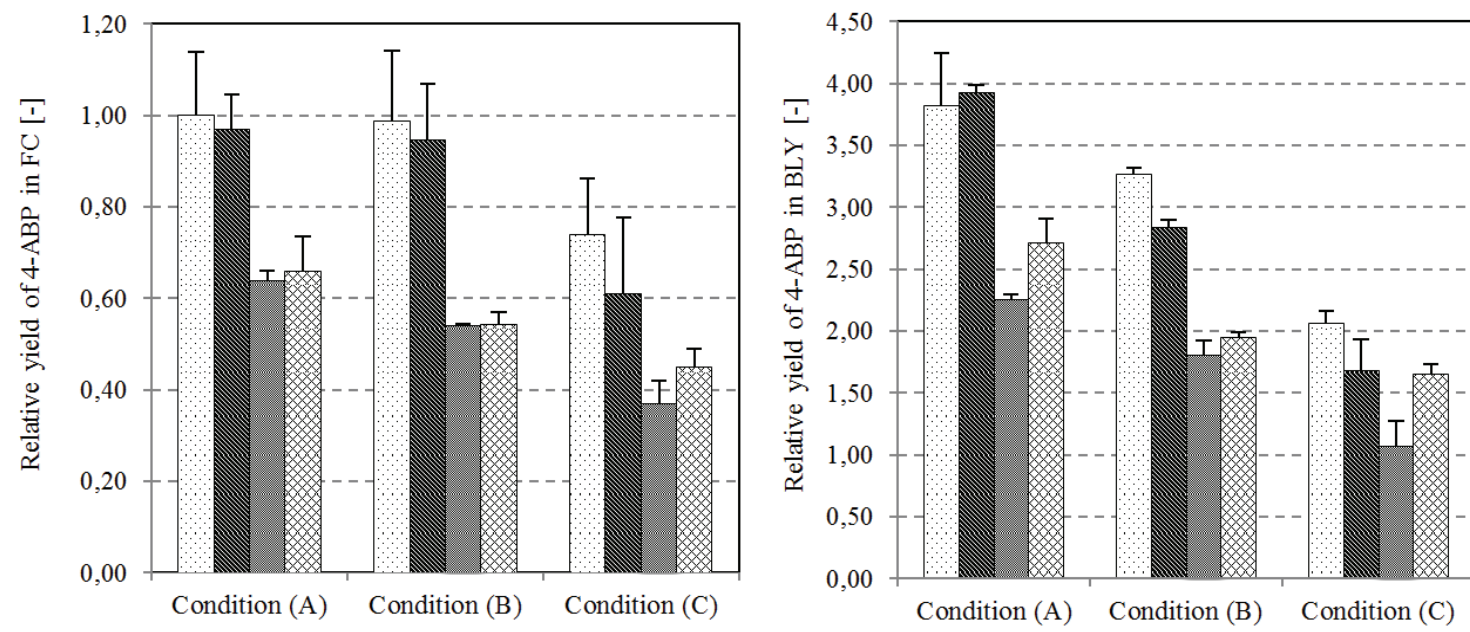

๑UCF

$\mathbb{M C E}$

$\square$ SWE

田IOA

Figure 7. Relative yield of 4-ABP in the pyrolysis of FC samples (left) and BLY samples (right) under three pyrolysis conditions. All results were normalized by the yields of FC-UCF under the condition (A). The conditions (A), (B) and (C) are indicated in Table 2.

${ }^{14} \mathrm{NH}_{4}{ }^{+}{ }^{15} \mathrm{NO}_{3}{ }^{-}$or ${ }^{15} \mathrm{NH}_{4}{ }^{+}{ }^{15} \mathrm{NO}_{3}{ }^{-}$under conditions like (A) in the present study (unpublished results). JOHNSON et al. also observed the reduction of nitrate to ammonia in sidestream cigarette smoke by using ${ }^{15} \mathrm{~N}$-labelled nitrate salt (19). This suggests that the reduction of nitrogen oxide to ammonia may occur in tobacco pyrolysis. Therefore, it seems that ammonium and nitrate ions in tobacco may work during tobacco pyrolysis as precursors for low molecular weight amines in reactions schematically outlined in Figure 8, although their contribution to the formation of 4-ABP in tobacco pyrolysis will depend on their level in tobacco.

The effects of the tobacco treatments on the yields of 1-AN and 3-ABP were similar to those of 2-AN and 4-ABP, respectively. As an exception, it was observed that the yield of 1-AN under the condition (A) was increased by the addition of the mixture of inorganic compounds in the case of FC and BLY, though the yield of 2-AN was NOT significantly changed (Table 7). It seemed that 1-AN, regio isomer of 2-AN, might have another formation pathway than 2-AN in tobacco pyrolysis.

These pyrolysis experiments under the three pyrolysis conditions showed that: 1) the nitrogen-containing organic compounds in the insoluble fraction of tobacco had the highest contribution to the yield of PAAs during tobacco pyrolysis; 2) the water-soluble fraction contained precursors of PAAs although the contribution of nitrate and ammonium ions varied according to the pyrolysis conditions; and 3) the methylene chloride-soluble fraction made only limited contributions to the formation of PAAs.

The samples of flue-cured cut filler, which were spiked with protoporphyrin or chlorophyllin (Figure 9) at $5 \mathrm{wt} \%$ were subjected to pyrolysis under conditions (A). The relative yields of each PAA are shown in Figure 10. They were NOT changed significantly by the addition of either protoporphyrin or chlorophyllin to tobacco.

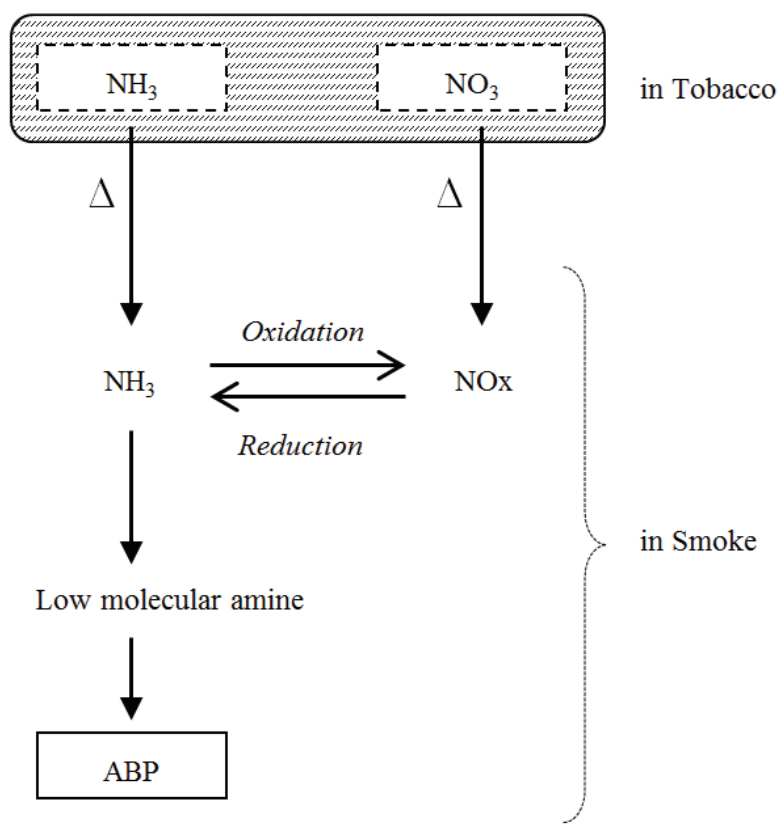

Figure 8. Proposed reaction scheme of ammonium and nitrate ions contributing to the formation of 4-ABP during tobacco pyrolysis.

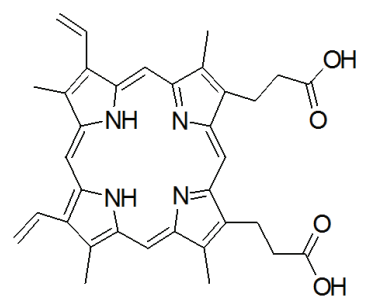

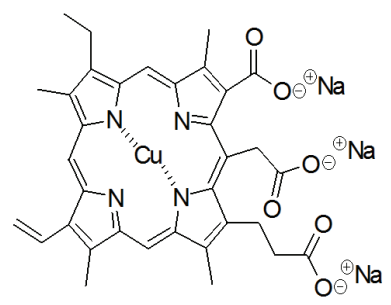

Figure 9. Chemical structure of protoporphyrin (left) and chlorophyllin (right). 
Table 10. Summary of the results obtained in the present study

\begin{tabular}{|c|c|c|c|c|}
\hline \multirow{2}{*}{ Tobacco type } & \multirow{2}{*}{ PAAs } & \multicolumn{3}{|c|}{ Contribution of each fraction to the whole yields of PAAs ${ }^{a}$} \\
\hline & & Methylene chloride-soluble fraction & Water-soluble fraction & Insoluble fraction \\
\hline \multirow{4}{*}{$\mathrm{FC}$} & $1-\mathrm{AN}$ & $\square / \square / \circ$ & $\bullet / \bullet / \bullet$ & $\bullet / \circ / \circ$ \\
\hline & 2-AN & $\square / \square / \circ$ & $\circ / \bullet / 0$ & $\bullet / \bullet / 0$ \\
\hline & 3-ABP & $\square / \square / \circ$ & $\circ / 0 / 0$ & $\bullet / \bullet / \bullet$ \\
\hline & 4-ABP & $\square / \square / \circ$ & $\circ / \bullet / \circ$ & $\bullet / \bullet / \bullet$ \\
\hline \multirow{6}{*}{ BLY } & $\begin{array}{l}\mathrm{N} \text {-Components in } \\
\text { the fraction }\end{array}$ & Nicotine $(50 \%)$ & $\begin{array}{l}\text { Nicotine }(50 \%), \mathrm{Amino} \text { acids, } \\
\text { Peptides, } \mathrm{NH}_{3} / \mathrm{NO}_{3}^{-}\end{array}$ & Proteins \\
\hline & $1-\mathrm{AN}$ & $\square / \square / \circ$ & $\circ / \circ / \circ$ & $\bullet / \bullet / \bullet$ \\
\hline & 2-AN & $\square / \circ / \circ$ & $\circ / \square / \square$ & $\bullet / \bullet / \bullet$ \\
\hline & 3-ABP & $\square / \square / \circ$ & $\circ / \circ / \circ$ & $\bullet / \bullet / \bullet$ \\
\hline & 4-ABP & $\square / \square / \bigcirc$ & $\bullet / \circ / 0$ & $\bullet / \bullet / \bullet$ \\
\hline & $\begin{array}{l}\mathrm{N} \text {-Components in } \\
\text { the fraction }\end{array}$ & Nicotine $(60 \%)$ & $\begin{array}{l}\text { Nicotine }(40 \%) \text {, Amino } \\
\text { acids, } \mathrm{NH}_{3} / \mathrm{NO}_{3}^{-}\end{array}$ & Proteins \\
\hline
\end{tabular}

a The square (口), the hollow circle triangle $(\circ)$, and the solid circle $(\bullet)$ stand for the ratios " $<0.15$ ", " $0.15-0.40$ ", and " $>0.40$ " for the contribution of each fraction to the whole yields of each PAA. The three symbols, separated by slashes, indicate the outcome under pyrolysis conditions $(A) /(B) /(C)$.

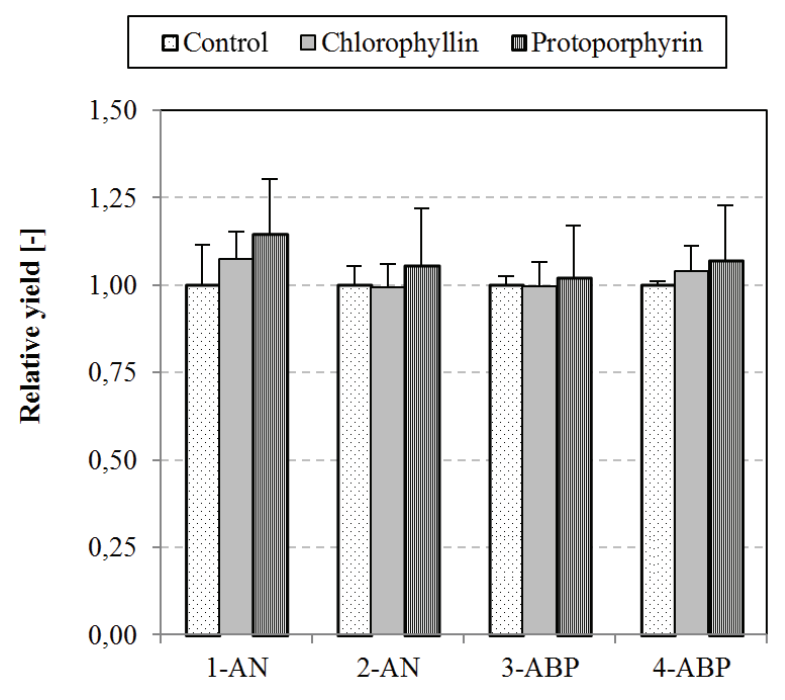

Figure 10. Relative yields of each PAA in the pyrolysis of tobacco spiked with porphine-containing compounds, normalized by the mean of the pyrolysis yield from the control sample under the pyrolysis conditions (A). Target temperature in a non-isothermal pyrolysis: $800{ }^{\circ} \mathrm{C} ; 0 \% \mathrm{O}_{2}$ in $\mathrm{N}_{2}$ carrier gas.

\section{DISCUSSION}

The results obtained in the present study are summarized in Table 10. The contribution of each fraction to the total yields of the four PAAs was defined as the ratio of the difference in the yield before and after treatment to the yield from UCF, except for SWE whose contribution was calculated as the ratio of the yield from SWE to that from UCF.

Since the methylene chloride-soluble fraction containing half of total nicotine did not show any contribution to the formation of PAAs, nicotine in tobacco seems NOT play a role in the formation of the four PAAs. It seems that the methylene chloride-soluble fraction contained low-molecu- lar weight N-heterocyclic compounds in tobacco, such as minor alkaloids, pyrroles and pyridines (20), due to their solubility in methylene chloride. These compounds, including nicotine, are assumed mainly to evaporate into smoke rather than being decomposed to amines during the pyrolysis of tobacco.

The present results indicated that the residual nicotine after the methylene chloride extraction step, ammonium ions, nitrate ions, amino acids and some protein-like compounds (peptides, water soluble proteins) were contained in the water-soluble fraction of tobacco. The amount of nicotine extracted with water is almost the same with FC and BLY (see the difference in nicotine quantities between $\mathrm{MCE}$ and SWE in Table 6). However, the effects on pyrolysis yields of PAAs by water extraction of BLY-MCE were 3 or 4 times those with FC-MCE (see the differences in PAAs quantities between MCE and SWE in Table 7, 8 and 9). Therefore, nicotine in the water-soluble fraction seems NOT to contribute to the formation of PAAs during tobacco pyrolysis. Regarding ammonium and nitrate ions, they may be precursors of the two aminobiphenyls under rather inert pyrolysis conditions, and their contribution would depend on their levels in tobacco. Consequently, it is likely that protein-like compounds, such as amino acids, peptides and water-soluble proteins, mainly contribute to the formations of PAAs as their precursors in the water-soluble fraction. In the present study, we focused on proteins as the nitrogenous components in the insoluble fraction. In addition to proteins, brown pigments and the decomposition products of chlorophyll, which are generated in tobacco during leaf curing (21), may be part of the insoluble fraction. CHORTYK et al. reported that the content of amino acids was calculated to be around $23 \mathrm{wt} \%$ in the brown pigments in Turkish tobacco (22). It is likely that the amino acid content in brown pigments contributes to the formation of PAAs as donator of amines, though the extent of the contribution is unclear.

Regarding the contribution of chlorophyll to the formation of PAAs, the addition of either protoporphyrin or chlorophyllin, which contain a porphine moiety like chlorophyll, 
to tobacco ( $5 \mathrm{wt} \%$ to wet tobacco) did NOT change the yield of the four PAAs in non-isothermal pyrolysis under an inert atmosphere up to $800{ }^{\circ} \mathrm{C}$. The total content of porphine-containing compounds in cured leaf is still unclear. However, it was reported that the level of chlorophyll in the tobacco leaf was about $0.8 \%$ of total leaf weight at an early curing stage, when chlorophyll content is highest during all curing stages (21). Although each porphine-containing compound was added to tobacco at $5 \%$ of total weight of tobacco cut filler in the present experiment, the addition of these compounds did NOT affect the pyrolysis yields of the four PAAs. Therefore, it is assumed that the nitrogen atom in the porphine compounds in tobacco does NOT work as a precursor of PAAs in tobacco pyrolysis. It seems that the pyrrole moiety of chlorophyll or other decomposition products in tobacco may be released into the smoke during the pyrolysis of tobacco and would not decompose into some low molecular weight amines, which could contribute to the formation of PAAs. It was speculated that nucleic acids exist in the water-soluble fraction or the insoluble fraction and are possible PAA precursors. However, as mentioned by TORIKAI et al. (9), nucleic acids may NOT contribute to the formation of PAAs due to their low content in tobacco.

\section{CONCLUSIONS}

In the present study, we carried out non-isothermal pyrolysis of tobacco samples obtained by sequential extraction and addition of inorganic compounds to the extracted residue, under three different pyrolysis conditions (target temperatures: $800{ }^{\circ} \mathrm{C} / 800{ }^{\circ} \mathrm{C} / 400{ }^{\circ} \mathrm{C}$ and $\mathrm{O}_{2}$ concentrations in $\mathrm{N}_{2}: 0 \% / 20 \% / 3 \%$ ). The yields of the four PAAs in the smoke generated during the pyrolysis of each sample were determined. Some nitrogenous compounds in the tobacco sample were also analyzed.

We concluded that mainly the protein-like components in tobacco, such as amino acids, peptides, proteins, and some compounds associated with amino acids, contribute to the formation of the four PAAs (1-AN, 2-AN, 3-ABP and 4ABP) in the pyrolysis of tobacco. Their contribution was in fact found to be over $80 \%$ of the total yield of each PAA. The present results support that endogenous protein-like components in tobacco contribute greatly to the formation of PAAs.

\section{ACKNOWLEDGEMENT}

The authors thank Ms. Maro Yamaguchi for her kind experimental assistance, and $\mathrm{Mr}$. Toru Tsujimoto for supplying the $2 \mathrm{R} 4 \mathrm{~F}$ and $3 \mathrm{R} 4 \mathrm{~F}$ cigarettes required for these studies.

\section{REFERENCES}

1. Haugen, D.A., M.J. Peak, K.M. Suhrbier, and V.C. Stamoudis: Isolation of Mutagenic Aromatic Amines From a Coal Conversion Oil by Cation Exchange Chromatography; Anal. Chem. 54 (1982) 32-37.
2. Akyüz, M.: Simultaneous Determination of Aliphatic and Aromatic Amines in Ambient Air and Airborne Particulate Matters by Gas Chromatography-Mass Spectrometry; Atmos. Environ. 42 (2008) 3809-3819.

3. Shelke M., S.K. Sanghi, A. Asthana, S. Lamba, and M. Sharma: Fast Separation and Sensitive Detection of Carcinogenic Aromatic Amines by Reversed-Phase Liquid Chromatography Coupled with Electrochemical Detection; J. Chromatogr. A 1089 (2005) 52-58.

4. Counts, M.E., M.J. Morton, S.W. Laffoon, R.H. Cox, and P.J. Lipowicz: Smoke Composition and Predicting Relationships for International Commercial Cigarettes Smoked with Three Machine-Smoking Conditions; Regul. Toxicol. Pharmacol. 41 (2005) 185-227.

5. Intorp, M. and S. Purkis: Determination of Aromatic Amines in Cigarette Mainstream Smoke - The CORESTA 2007 Joint Experiment; Beitr. Tabakforsch. Int. 24 (2010) 78-92.

6. Stabbert, R., K.H. Schäfer, C. Biefel, and K. Rustemeier: Analysis of Aromatic Amines in Cigarette Smoke; Rapid Commun. Mass Spectrom. 17 (2003) 2125-2132.

7. Smith, C.J., G.L. Dooly, and S.C. Moldoveanu: New Technique Using Solid-Phase Extraction for the Analysis of Aromatic Amines in Mainstream Cigarette Smoke; J. Chromatogr. A 991 (2003) 99-107.

8. Patrianakos, C. and D. Hoffmann: Chemical Studies on Tobacco Smoke. LXIV. On the Analysis of Aromatic Amines in Cigarette Smoke; J. Anal. Toxicol. 3 (1979) 150-154.

9. Torikai K., Y. Uwano, T. Nakamori, W. Tarora, and H. Takahashi: Study on Tobacco Components Involved in the Pyrolytic Generation of Selected Smoke Constituents; Food Chem. Toxicol. 43 (2005) 559-568.

10. Nowakowski, D.J. and J.M. Jones: Uncatalysed and Potassium-Catalysed Pyrolysis of the Cell-Wall Constituents of Biomass and Their Model Compounds; J. Anal. Appl. Pyrolysis 83 (2008) 12-25.

11. Kleen, M. and G. Gellerstedt: Influence of Inorganic Species on the Formation of Polysaccharide and Lignin Degradation Products in the Analytical Pyrolysis of Pulps; J. Anal. Appl. Pyrolysis 35 (1995) 15-41.

12. Roemer, E., H. Schramke, H. Weiler, A. Buettner, S. Kausche, S. Weber, A. Berges, M. Stueber, M. Muench, E. Trelles-Sticken, J. Pype, K. Kohlgrueber, H. Voelkel, and S. Wittke: Mainstream Smoke Chemistry and In Vitro and In Vivo Toxicity of the Reference Cigarettes 3R4F and 2R4F; Beitr. Tabakforsch. Int. 25 (2012) 316-335.

13. International Standardization Organization (ISO): ISO 3308. Routine Analytical Cigarette Smoking Machine Definitions and Standard Conditions. ISO, Geneva, Switzerland, 2000.

14. Bokelman, G. H. and W.S. Ryan Jr.: Analyses of Bright and Burley Tobacco Laminae and Stems; Beitr. Tabakforsch. Int. 13 (1985) 29-36.

15. Health Canada: Determination of $\mathrm{Ni}, \mathrm{Pb}, \mathrm{Cd}, \mathrm{Cr}, \mathrm{As}, \mathrm{Se}$ and $\mathrm{Hg}$ in Whole Tobacco; T-306, Health Canada, 1999, available at http:/www.hc-sc.gc.ca/hc-ps/ alt_formats/hecs-sesc/pdf/tobac-tabac/legislation/reg/i ndust/method/_whole-entier/metal-eng.pdf.

16. Torikai, K., S. Yoshida, and H. Takahashi: Effects of 
Temperature, Atmosphere and $\mathrm{pH}$ on the Generation of Smoke Compounds During Tobacco Pyrolysis; Food Chem. Toxicol. 42 (2004) 1409-1417.

17. Baker, R.R.: Variation of the Gas Formation Regions within a Cigarette Combustion Coal During the Smoking Cycle; Beitr. Tabakforsch. Int. 11 (1981) 1-17.

18. Baker, R.R.: A Review of Pyrolysis Studies to Unravel Reaction Steps in Burning Tobacco; J. Anal. Appl. Pyrolysis 11 (1987) 555-573.

19. Johnson, W.R., R.W. Hale, S.C. Clough, and P.H. Chen: Chemistry of the Conversion of Nitrate Nitrogen to Smoke Products; Nature 243 (1973) 223-225.

20. Schmeltz, I. and D. Hoffmann: Nitrogen-Containing Compounds in Tobacco and Tobacco Smoke; Chem. Rev. 77 (1977) 295-311.

21. Leffingwell, J.C.: Leaf Chemistry. Basic Chemical Constituents of Tobacco Leaf and Difference Among Tobacco Types; in: Tobacco Production, Chemistry and Technology, edited by D.L. Davis and M.T. Nielsen, Blackwell Science, Oxford, 1999, pp. 265-284.
22. Chortyk, O.T., W.S. Schlotzhauer, and R.L. Stedman: Composition Studies on Tobacco. XXIII. Pyrolytic and Structural Investigations on the Polyphenol-Amino Acid Pigments of Leaf; Beitr. Tabakforsch. 3 (1966) 422-429.

Corresponding author:

Shinya Yoshida

Tobacco Science Research Center

Japan Tobacco Inc.

6-2, Umegaoka, Aoba-ku, Yokohama, Kanagawa, Japan

E-mail: shinya.a.yoshida@jt.com 